\title{
Gross morphology of the brain of Pseudopimelodus bufonius (Valenciennes, 1840) (Siluriformes: Pseudopimelodidae)
}

\author{
Vitor Pimenta Abrahão and Oscar Akio Shibatta
}

\begin{abstract}
The gross morphology of the brain of the pseudopimelodid Pseudopimelodus bufonius is described and compared with congeners. Observations were made on removed brains after elimination of bones from the top of the skull and severing of the cranial nerves and the spinal cord. Nine morphometric characters associated with the major subdivisions of the brain were identified, seven of which revealed significant differences among the species examined. The corpus cerebelli in all examined species of the genus is the largest structure of the brain. The behavior of the species of Pseudopimelodus is still unknown, but in other teleosts that condition is typically correlated with a higher degree of motor coordination. Relative size proportions of the tectum opticum, eminentia granularis, lobus facialis and lobus vagi, might be related to carnivory and an enhanced capacity for food selection.

A morfologia externa do encéfalo de Pseudopimelodus bufonius é descrita e comparada com seus congêneres. As análises foram feitas no cérebro removido após a eliminação dos ossos do topo da cabeça e secção dos nervos cranianos e cordão espinhal. Nove caracteres morfométricos foram obtidos das principais subdivisões do encéfalo, dos quais em sete ocorreram diferenças significativas entre as espécies. Em todas as espécies examinadas do gênero o corpus cerebelli é a maior estrutura do encéfalo. O comportamento das espécies de Pseudopimelodus ainda é desconhecido, mas em outros teleósteos esta característica é normalmente correlacionada com uma boa coordenação motora. Além disso, as proporções relativas do tectum opticum, eminentia granularis, lobus facialis e lobus vagi podem ser relacionadas a hábitos carnívoros e boa capacidade de selecionar alimentos.
\end{abstract}

Keywords: Behavior, Catfishes, Comparative Morphology, Neotropical fishes, Neuroanatomy.

\section{Introduction}

The neurological system of fi hes has been greatly neglected in systematics studies. Within Teleostei, the major lineages are primarily supported by osteological and molecular synapomorphies. It is estimated that almost three-quarters of the total morphological information related to phylogenetic reconstruction is related to skeletal features (Wiley \& Johnson, 2010). Datovo \& Vari (2014) in a comprehensive review of morphological features used in fi h systematics, found a similar predominance of osteological characters (74\%) in relation to other sets of data. According to those authors, $6 \%$ corresponded to myology, $5 \%$ to splanchnology, $14 \%$ to other morphological characters (e.g. associated structures of external morphology and reproductive system), and only $1 \%$ to neurology.

The brain of vertebrates is basically divided into regions that control specific functions related to sense organs, motor coordination, behavior and metabolic regulation (Butler $\&$ Hodos, 2005). The size of a particular structure in the brain typically indicates the predominance of its function and/or the accuracy of the sense to which it is related. Evans (1931) examined the brains of cyprinids, to evaluate feeding behavior and diet composition with regard to the size of gustative lobes (lobus facialis and lobus vagi). In a series of studies, Eastman \& Lannoo (1995, 2001, 2003a, 2003b, 2004, 2007, 2008, 2011) found phylogenetic, ecologic and behavior correlations with format and size of brain structures in Antarctic icefishes (Nototheniiformes). Studies on brain evolution in the Teleostei have also been conducted by Ito et al. (2007) on the development of main regions of the brain, and Northcutt $(2004,2008)$ on the development of gustative lobes and of forebrain. More recently, some authors have focused on the association of development and behavioral responses over the brain structures (Gonda et al., 2011; Kotrschal et al., 2012; Lecchini et al., 2014).

Among catfishes, the neuroanatomy is better understood in the North American Ictaluridae (see Atema, 1971; Lundberg, 1982; Tong \& Finger, 1983; Meek \& Nieuwenhuys, 1998). The brain anatomy of the Callichthyidae and its relation to the phylogeny of the group was discussed by Pupo (2011), and recently, Rosa et al. (2014) detailed the gross morphology of the brain of Neotropical catfi hes. The systematics and anatomy of the Pseudopimelodidae have been the subject of several studies (e.g., Lundberg et al., 1991; Shibatta, 1998, 2003; Birindelli \& Shibatta, 2011), but descriptions of the gross morphology of the brain in the group (and of the Siluriformes as a whole) remain scarce.

Programa de Pós-Graduação em Ciências Biológicas, Departamento de Biologia Animal e Vegetal, Universidade Estadual de Londrina, Caixa Postal 10.011, 86057-970 Londrina, PR, Brazil. (VPA) vitorabrahao32@gmail.com (corresponding author), (OAS) shibatta@uel.br 
Pseudopimelodus bufonius (Valenciennes, 1840) (Fig. 1) is the type species of the genus, which in turn is the type genus of the family (Shibatta, 2003a). Pseudopimelodidae includes five additional genera and about 32 valid species, among of them are four species of Pseudopimelodus (Shibatta, 2003b; Ruiz \& Shibatta, 2011). The group is widely distributed throughout the Neotropical region, from the río Atrato in Colombia to the río de la Plata in Argentina (Lundberg et al., 1991). Interestingly, species of Pseudopimelodus have small eyes and wide mouths, which suggest low dependence on vision, nocturnal activity, and predatory habits (Shibatta, 2013). Herein, we for the first time describe the gross morphology of the brain and the major cranial nerves in $P$. bufonius. We further compare it to the brain anatomy of two congeners, $P$. charus (Valenciennes, 1840) and P. mangurus (Valenciennes, 1835), and comment on correlation between the morphology of the brain and behavior.

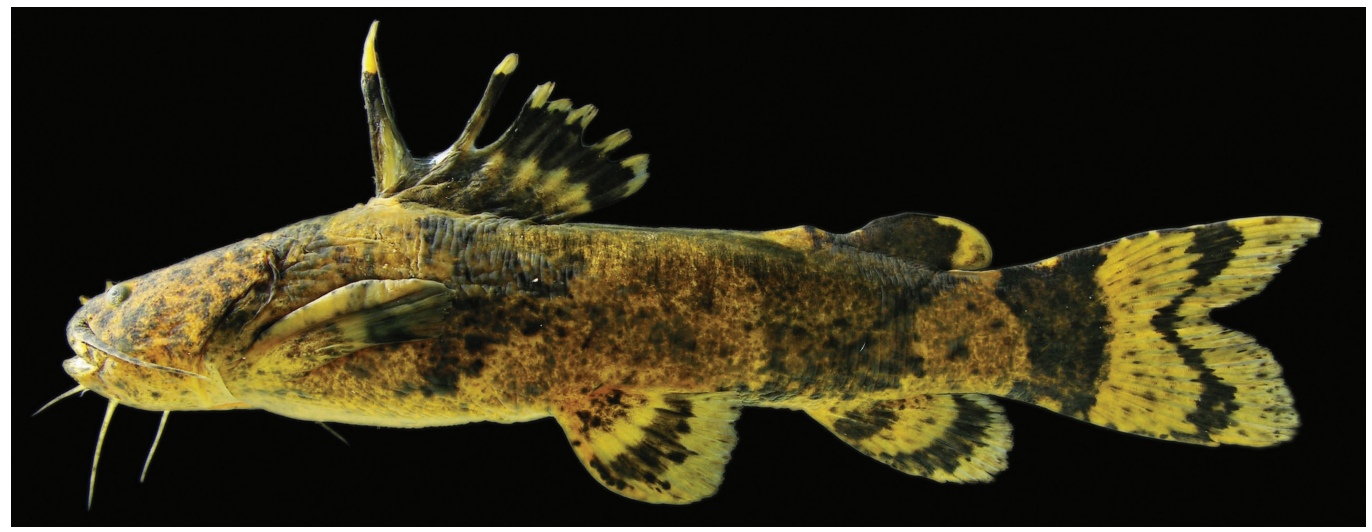

Fig. 1. Pseudopimelodus bufonius, MZUSP 94855, $113.3 \mathrm{~mm}$ SL; Brazil, Mato Grosso, Paranatinga, rio Culuene, tributary of the rio Xingu. Photo by José L. O. Birindelli.

\section{Material and Methods}

Six specimens of P. bufonius (97.8-118.2 $\mathrm{mm} \mathrm{SL})$, three specimens of P. mangurus $(88.5-175.4 \mathrm{~mm} \mathrm{SL})$, and one specimen of $P$. charus $(123.7 \mathrm{~mm} \mathrm{SL})$ were dissected. Dissections were performed in the following sequence (see Abrahão \& Pupo, 2014, for more detail and illustrations): the skin covering the skull bones surrounding the supraoccipital process was removed, typically scraping it off with a mini spatula. To avoid damaging brain subdivisions and nerves during dissection, it was necessary to infer their positions in relation to cranial bones (Fig. 2). Incisions were made with a dental drill powered by a suspended electric motor in the sutures between the pterotic, sphenotic, and frontal, forming a circle around the supraoccipital process, which was then removed carefully using forceps. Cross-sections were made with a scalpel on the medulla spinalis, nervus vagus (nX), nervus glossopharyngeus (nIX), nervus octavus (nVIII), nervus facialis (nVII), nervus abducens (nVI), nervus trigeminus (nV), nervus trochlearis (nIV), nervus oculomotorius (nIII), nervus linea lateralis anterior (nlla), nervus linea lateralis posterior (nllp), nervus opticus (nII) and nervus tractus olfactorius (ntol) (Figs. 2-5). To remove the brain and the associated olfactory bulb and nervus olfactorius (nI), incisions were made in the frontal bone and mesethmoid to reach the olfactory organ, removing it while avoiding incisions that could damage the olfactory tract (Fig. 2). The nomenclature of the brain regions follows Meek \& Nieuwenhuys (1998) and Butler \& Hodos (2005). The brains were kept in $4 \%$ formalin buffered with $\mathrm{CaCO}_{3}$, after removal from the neurocranium. All specimens were preserved in $70 \%$ ethanol after fixation in $4 \%$ formalin.

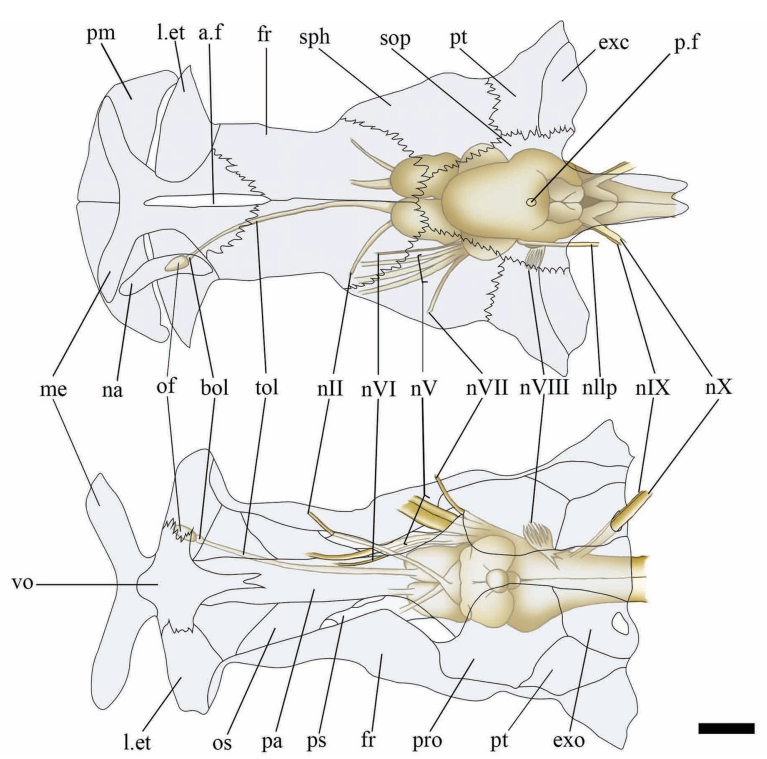

Fig.2.Diagramaticrepresentation ofbrainandneurocranium of Pseudopimelodus bufonius, MZUEL 5744, $116.4 \mathrm{~mm}$ $\mathrm{SL}$, in dorsal and ventral views. a.f: anterior fontanel; bol: bulbus olfactorius; exc: extrascapula; exo: exoccipital; fr: frontal; 1.et: lateral ethmoid; me: mesethmoid; na: nasal; nII: nervus opticus; $\mathrm{nV}$ : nervus trigeminus; $\mathrm{nVI}$ : nervus abducens; nVII: nervus facialis; nVIII: nervus octavus; nIX: nervus glossopharyngeus; NX: nervus vagus; Nllp: nervus linea lateralis posterior; of: olfactory epithelium; os: orbitosphenoid; pa: parasphenoid; pm: premaxillary; pro: prootic; ps: pterosphenoid; pt: pterotic; p.f: posterior fontanel; sop: supraoccipital process; sph: sphenotic; tol: nervus tractus olfactorius; vo: vomer. Scale bar $=2 \mathrm{~mm}$. 

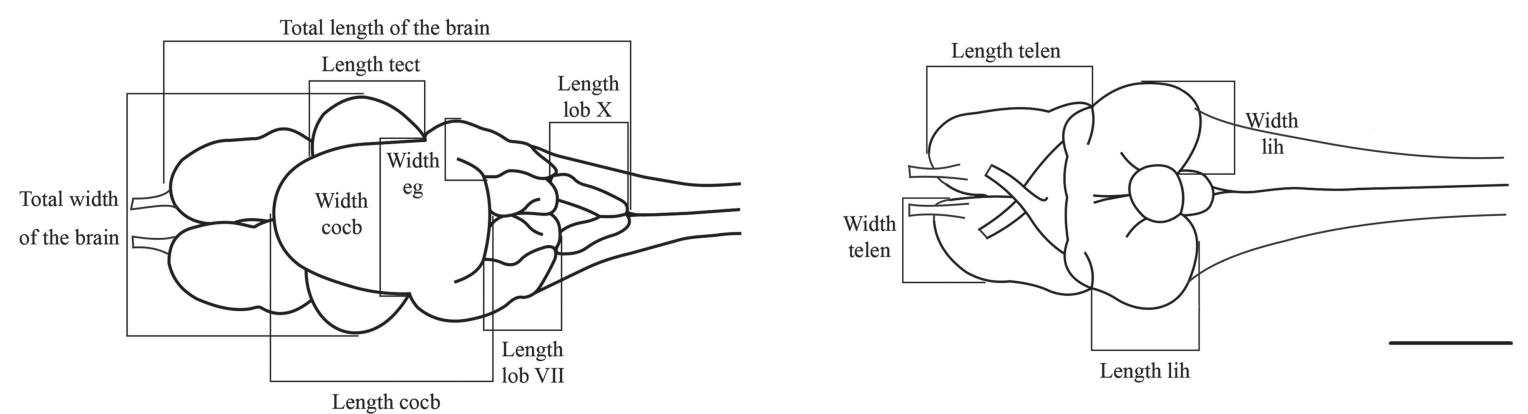

Fig. 3. Diagramatic representation of measurements of major subdivisions of the brain of Pseudopimelodus bufonius, MZUEL 5744, $116.4 \mathrm{~mm}$ SL, in dorsal and ventral views. Cocb: corpus cerebelli; eg: eminentia granularis; lih: lobus inferior hypothalami; lobVII: lobus facialis; lobX: lobus vagi; telen: telencephalon; tect: tectum opticum. Scale bar $=2 \mathrm{~mm}$.
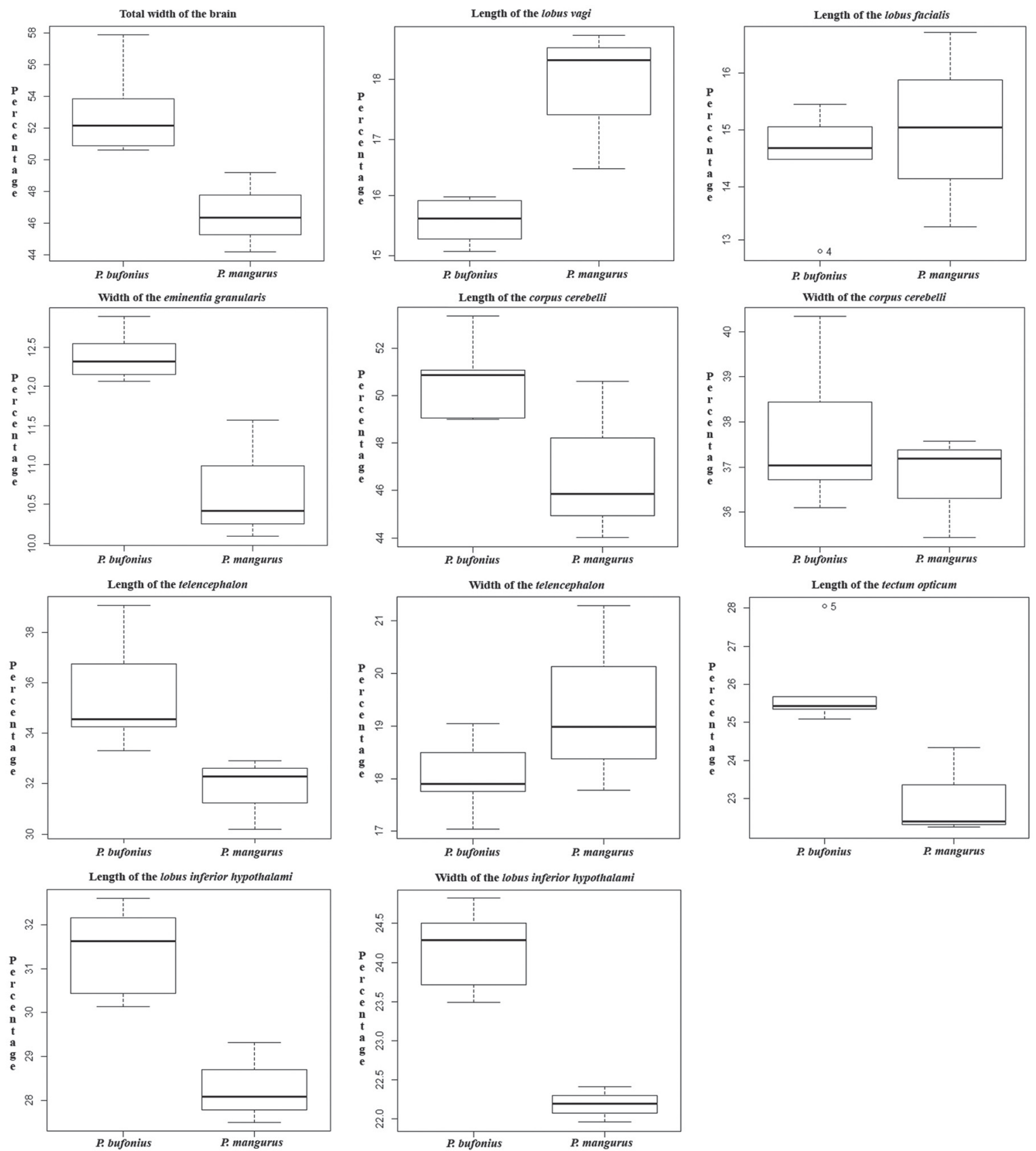

Fig. 4. Boxplot proportions of major subdivisions measurements of Pseudopimelodus bufonius and P. mangurus brains. 


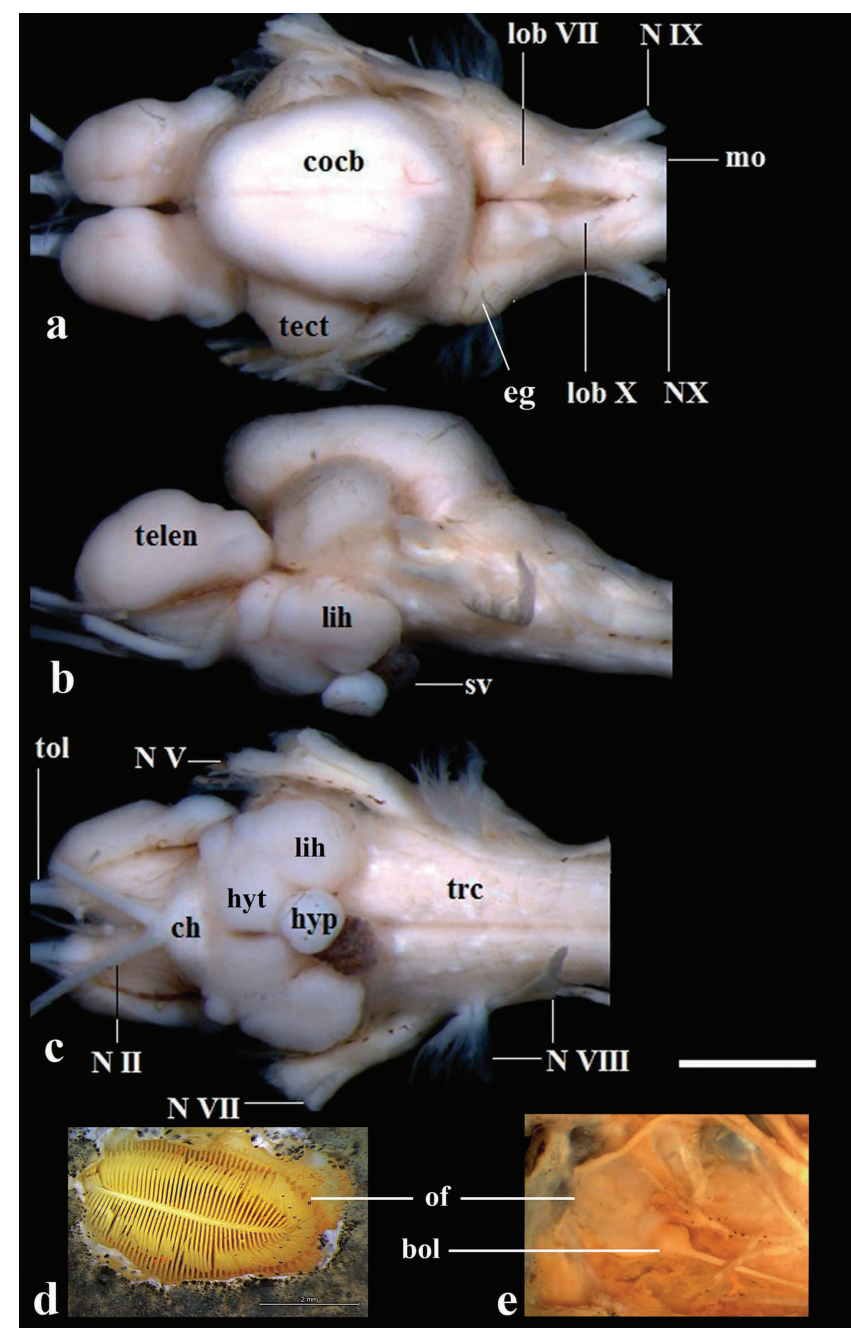

Fig. 5. Brain of Pseudopimelodus bufonius, MZUEL $5744,118.2 \mathrm{~mm} \mathrm{SL}$, in (a) dorsal, (b) lateral and (c) ventral views, and (d) dorsal and (e) ventral views of olfactory organ. bol: bulbus olfactorius; ch: chiasma opticum; cocb: corpus cerebelli; eg: eminentia granularis; lih: lobus inferior hypothalami; hyp: hypophysis; hyt: hypothalamus; lobVII: lobus facialis; lobX: lobus vagi; mo: medulla oblongata; NII: nervus opticus; NV: nervus trigeminus; NVII: nervus facialis; NVIII: nervus octavus; NIX: nervus glossopharyngeus; NX: nervus vagus; of: olfactory organ; sv: saccus vasculosus; trc: truncus cerebri; telen: telencephalon; tect: tectum opticum; tol: nervus tractus olfactorius. Scale bar $=2 \mathrm{~mm}$.

A digital camera attached to a stereomicroscope was used to capture images of the brain topography. The following measurements were taken using the software Axio Vision Rel v.4.8 (Zeiss, 2009): vagal lobe length, facial lobe length, eminentia granularis width, corpus cerebelli length, corpus cerebelli width, telencephalon length, telencephalon width, tectum opticum length, lobus inferior hypothalami length, and lobus inferior hypothalami width. Table 1 shows these measurements in proportion to the total brain length (BL), measured from the anterior portion of the telencephalon to the most posterior portion of the lobus vagi (modified from Lannoo \& Eastman, 2000; Fig. 3). Only the lobus inferior hypothalami was measured in the diencephalon (Figs. 3, 5, 7). R (Ihaka \& Gentleman, 1996) was used to assess differences in measurements in a boxplot. This statistical test is appropriated to summarize and compare data sets graphically. It uses median, approximate quartiles and maximum and minimum data point in order to assess the spread and distribution of sample values.

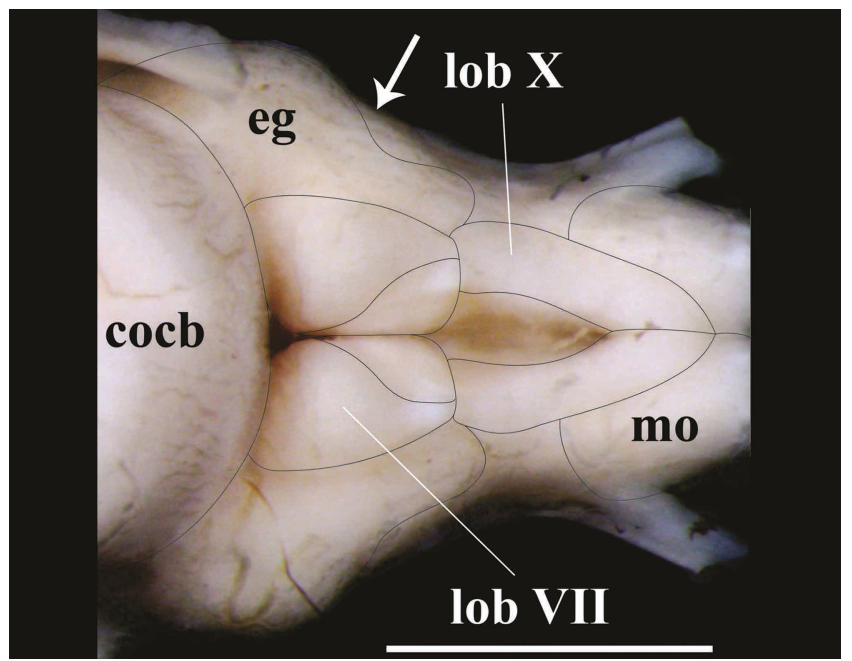

Fig. 6. Posterior portion of rhombencephalon of Pseudopimelodus bufonius, MZUEL 5744, $118.2 \mathrm{~mm}$ SL, dorsal view. cocb: corpus cerebelli; eg: eminentia granularis; lobVII: lobus facialis; lobX: lobus vagi; mo: medulla oblongata. Arrow indicates the separation point between anterior and posterior bulges of the eminentia granularis. Scale bar $=2 \mathrm{~mm}$.

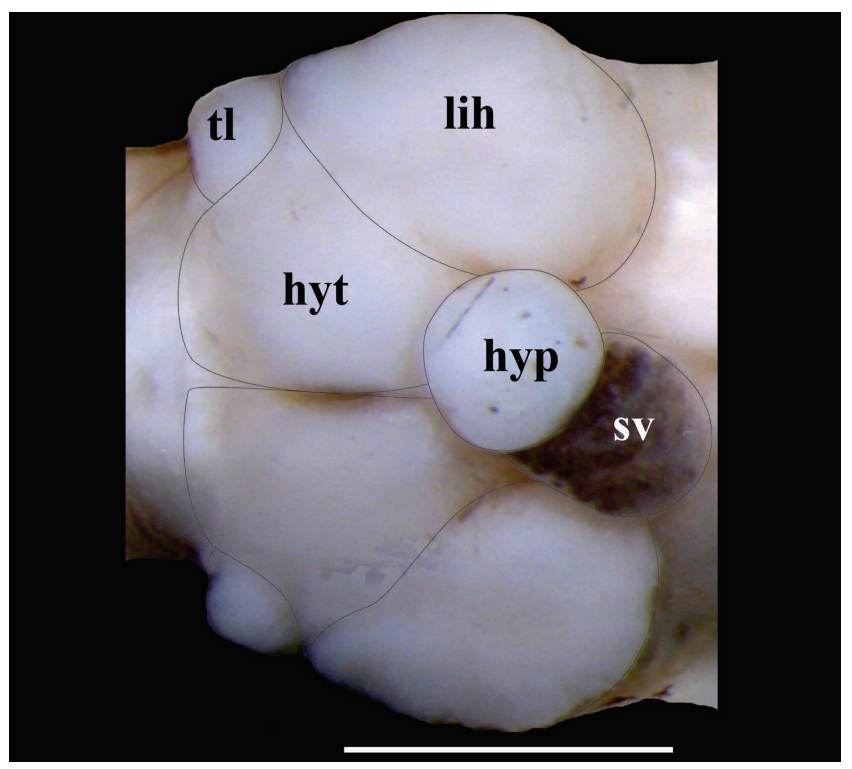

Fig. 7. Diencephalon of Pseudopimelodus bufonius, MZUEL 5744, $118.2 \mathrm{~mm}$ SL, ventral view. hyp: hypophisis; hyt: hypothalamus; lih: lobus inferior hypothalami; tl: torus lateralis; sv: saccus vasculosus. Scale bar $=2 \mathrm{~mm}$. 


\section{Results}

The brain is completely located beneath the supraoccipital process and above the parasphenoid and prootic in species of Pseudopimelodus, with exception of the bulbus olfactorius and part of the anterior portion of the telencephalon (Fig. $2)$. Brain width in relation to $\mathrm{BL}$ is significantly larger $(\mathrm{p}=0.01)$ in $P$. bufonius (mean $=53.1 \%$ ) than in the other examined species, whereas in P. mangurus it is the smallest (mean $=46.6 \%$; Table 1; Fig. 4). Descriptions below are based on $P$. bufonius, with comments on examined congeners.

Rhombencephalon. In all examined species of Pseudopimelodus, the medulla oblongata is located above to efferent projections of nervus vagus to medulla spinalis, and also located dorsally in relation to the truncus cerebri, and posterolaterally to the lobus vagi. The medulla oblongata is composed of two ovoid-shaped structures contacting the medulla spinalis. The posterior portion of those structures is slightly smaller than their anterior counterparts, each of which is conspicuously intumescent (Figs. 5-6, 8).

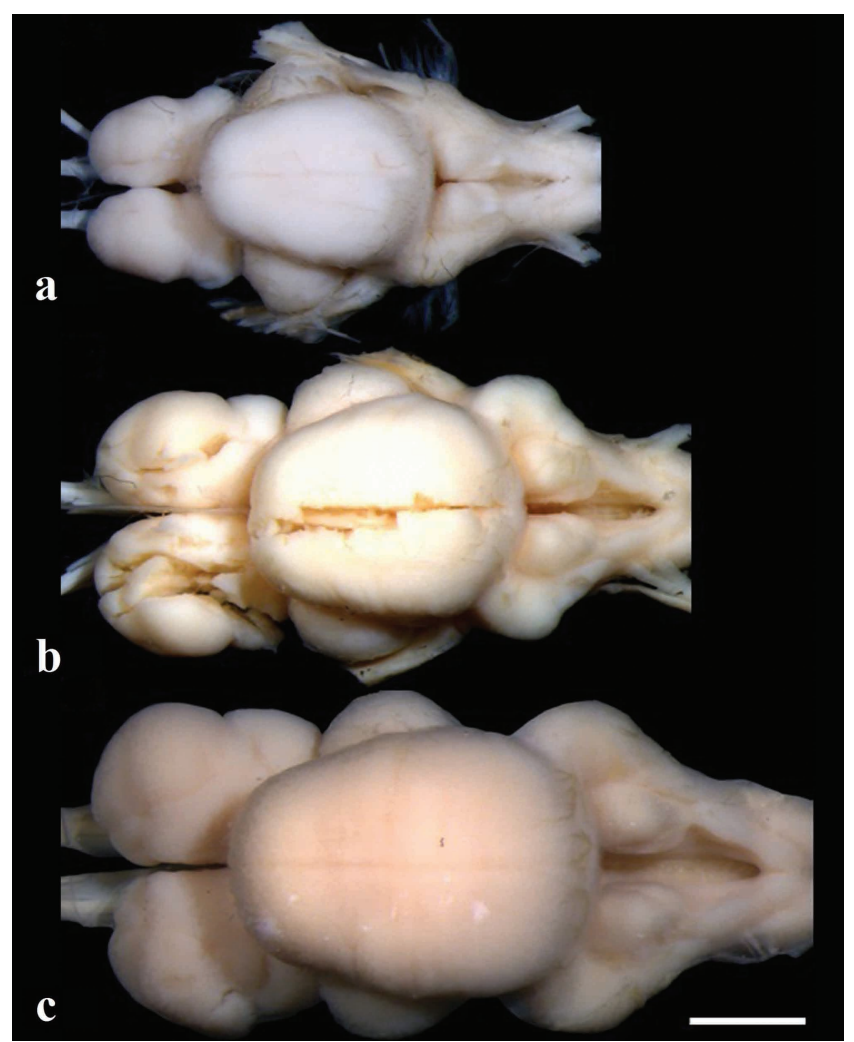

Fig. 8. Brain in dorsal view: (a) Pseudopimelodus bufonius, MZUEL 5744, $118.2 \mathrm{~mm}$ SL, (b) P. charus, MZUEL 6488, $123.7 \mathrm{~mm}$ SL, (c) P. mangurus, MZUEL 2795, $175.7 \mathrm{~mm}$ SL. Scale bar $=2 \mathrm{~mm}$.

The lobus vagi is located at the dorsal portion of the rhombencephalon. In dorsal view, it is immediately posterior to the lobus facialis, and anteromedially located in relation to the medulla oblongata. The lobus vagi is composed of two V-shaped cylindrical paired lobes, whose posterior portion contact each other, forming an acute tip (Figs. 5-6, 8). The length of the lobus vagi is shorter than the length of the tectum opticum, but is longer than the lengths of the lobus facialis and the eminentia granularis. The lobus vagi length in relation to BL is significantly longer $(\mathrm{p}=0.005)$ in P. mangurus (Table 1, Fig. 4).

The lobus facialis is located at the dorsal portion of the rhombencephalon, posterior to the corpus cerebelli, anterior to the lobus vagi, and medially located in relation to the eminentia granularis. A small portion of the anterior area of the lobus facialis is under the posterior portion of the corpus cerebelli. The lobes of the lobus facialis are longitudinally elongated, each approximately rhomboidshaped, but with rounded edges. A conspicuous bulge is anterolaterally anchored to each lobe. The lobes of the lobus facialis are parallel, but do not contact one another, though both contact the corpus cerebelli anteriorly (Figs. 5, $6,8)$. The length of the lobus facialis is shorter lengthwise than the lobus vagi and tectum opticum, and proportionally longer than the length of the eminentia granularis. The length of lobus facialis in relation to the BL is longer in $P$. mangurus (Table 1, Fig. 4).

The eminentia granularis is prominent in the examined species of Pseudopimelodus (Figs. 4-5), and is located at the dorsal portion of the rhombencephalon, posterolaterally to the corpus cerebelli and lateral to the lobus facialis. The structure has two conspicuous rounded bulges, the anterior one more prominent than the posterior. The anterior bulge is positioned at the posterolateral portion of the corpus cerebelli, extending up to approximately, but a little less than half the length of the lobus facialis. The posterior bulge extends to the anterior area of the lobus vagi (Figs. $5,6,8)$. In terms of lengths, the eminentia granularis is longer than the medulla oblongata and shorter than both the lobus facialis and lobus vagi. The length of the eminentia granularis in relation to BL is significantly longer $(\mathrm{p}=0.004)$ in P. bufonius (Table 1, Fig. 4).

The corpus cerebelli is located at the dorsal portion of the rhombencephalon, immediately anterior to the lobus facialis, dorsal to the hypothalamus, and medial to the tectum opticum. The anterior portion of the structure is dorsal to the posterior region of the telencephalon. The corpus cerebelli is ovoid in shape, with the anterior portion slightly smaller than the posterior one. The anterior margin of the corpus cerebelli is rounded, whereas its posterior margin is flap-shaped. The dorsal region of the corpus cerebelli in lateral view and the lateral margins on dorsal view are straight, without any conspicuous undulations. The length of the structure is slightly less than half the length of the telencephalon (Fig. 5, 8, 9). The mean of corpus cerebelli length in relation to $\mathrm{BL}$ is longer in $P$. bufonius (Fig. 4). In all examined species of Pseudopimelodus, the corpus cerebelli is the largest subdivision of brain (Figs. 5-9, Table 1). 
Table 1. Morphometry of brain on Pseudopimelodus species. Total length of brain (BL) in millimeters, other data on percentages to $\mathrm{BL}$. Min = minimum; $\max =$ maximum; $\mathrm{sd}=$ standard deviation; $\mathrm{CV}=$ coefficient of variation

\begin{tabular}{|c|c|c|c|c|c|c|}
\hline & \multicolumn{3}{|c|}{ P. bufonius $(\mathrm{N}=6)$} & \multicolumn{3}{|c|}{ P. mangurus $(\mathrm{N}=3)$} \\
\hline & Min-max & mean \pm sd & CV $(\%)$ & $\min -\max$ & mean \pm sd & $\mathrm{CV}(\%)$ \\
\hline Total length of the brain (BL, mm) & $8.4-9.4$ & $8.7 \pm 0.4$ & 4.7 & $7.93-12.4$ & $10.6 \pm 2.4$ & 22.4 \\
\hline \multicolumn{7}{|c|}{ Percentages of BL } \\
\hline Total width of the brain & $50.6-57.9$ & $53.1 \pm 2.9$ & 5.6 & $44.2-49.2$ & $46.6 \pm 2.5$ & 5.4 \\
\hline Length of vagal lobe & $15.1-16.0$ & $15.6 \pm 0.4$ & 2.5 & $16.5-18.7$ & $17.8 \pm 1.2$ & 6.6 \\
\hline Length of facial lobe & $12.8-15.4$ & $14.5 \pm 1.0$ & 7.0 & $13.2-16.7$ & $15.0 \pm 1.7$ & 11.6 \\
\hline Width of eminentia granularis & $12.1-12.9$ & $12.4 \pm 0.3$ & 2.7 & $10.1-11.6$ & $10.7 \pm 0.8$ & 7.3 \\
\hline Length of corpus cerebelli & $49.0-53.3$ & $50.7 \pm 1.8$ & 3.5 & $44.0-50.6$ & $46.8 \pm 3.4$ & 7.3 \\
\hline Width of corpus cerebelli & $36.1-40.3$ & $37.7 \pm 1.7$ & 4.5 & $35.4-37.6$ & $36.7 \pm 1.1$ & 3.1 \\
\hline Length of telencephalon & $33.3-39.0$ & $35.6 \pm 2.3$ & 6.5 & $30.2-32.9$ & $31.8 \pm 1.4$ & 4.5 \\
\hline Width of telencephalon & $17.0-19.0$ & $18.0 \pm 0.8$ & 4.2 & $17.8-21.3$ & $19.3 \pm 1.8$ & 9.2 \\
\hline Length of tectum opticum & $25.1-28.0$ & $25.9 \pm 1.2$ & 4.7 & $22.2-24.3$ & $23.0 \pm 1.2$ & 5.1 \\
\hline Length of lobus inferior hypothalami & $30.1-32.6$ & $31.4 \pm 1.1$ & 3.4 & $27.5-29.3$ & $28.3 \pm 0.9$ & 3.3 \\
\hline Width of lobus inferior hypothalami & $23.5-24.8$ & $24.2 \pm 0.6$ & 2.3 & $22.0-22.4$ & $22.2 \pm 0.2$ & 1.0 \\
\hline
\end{tabular}

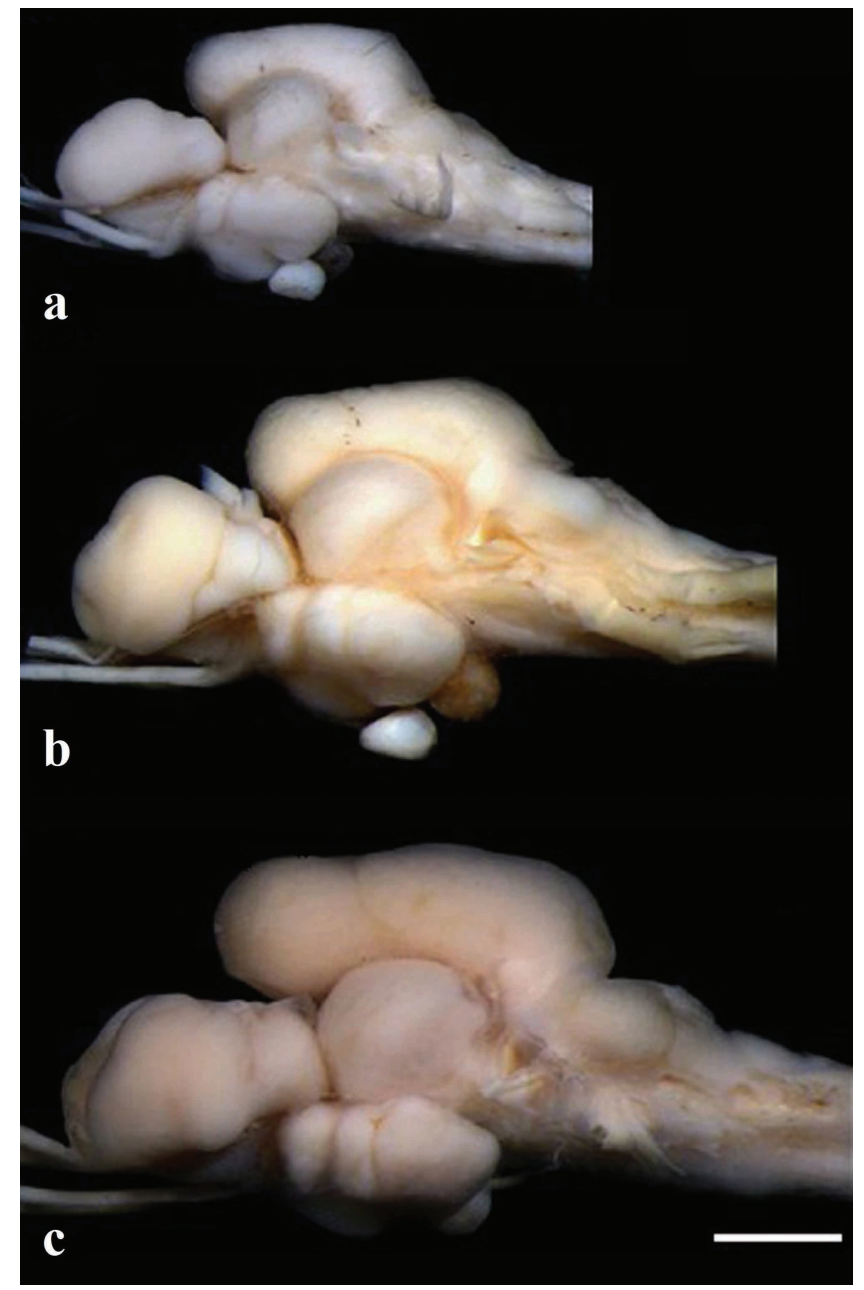

Fig. 9. Brain in lateral view: (a) Pseudopimelodus bufonius, MZUEL 5744, $118.2 \mathrm{~mm}$ SL, (b) P. charus, MZUEL 6488, $123.7 \mathrm{~mm} \mathrm{SL}$, (c) P. mangurus, MZUEL 2795, $175.7 \mathrm{~mm}$ SL. Scale bar $=2 \mathrm{~mm}$. (The hypophysis of $P$. mangurus is not shown because it was damaged during dissections).
The nervus glossopharyngeus and the nervus vagus emerge from the lateral wall of the rhombencephalon, at approximately the mid-point of the lobus vagi, exiting the efferent projections of the braincase through a foramen on the exoccipital. The nervus octavus, the nervus linea lateralis anterior and the nervus linea lateralis posterior emerge from the ventrolateral wall of the rhombencephalon, at approximately the midpoint of the eminentia granularis. The nervus facialis and the nervus trigeminus emerge from the ventrolateral portion of the rhombencephalon, anterior to the nervus octavus, and their efferent projections of the braincase through foramina on the parasphenoid, prootic, sphenotic and pterosphenoid. The anterior ramus of the nervus trigeminus and the nervus linea lateralis anterior have efferent projections from the braincase through a single foramen between the orbitosphenoid and pterosphenoid (Fig. 2).

Mesencephalon. The tectum opticum is located at the dorsal portion of the tegumentum mesencephali, anterolateral to the corpus cerebelli in dorsal view, and posterior to the telencephalon in lateral view. The tectum opticum has two bilaterally-rounded structures, which contact both the corpus cerebelli and the telencephalon (Figs. 5, 8, 9). The length of the tectum opticum is longer than that of the lobus vagi, lobus facialis and eminentia granularis. The length of the tectum opticum in relation to BL is significantly longer $(\mathrm{p}=0.01)$ in P. bufonius (Table 1, Fig.4).

The nervus opticus emerges from the tectum opticum on the mesencephalon, and efferent projections exit in the region immediately anterior to the lobus inferior hypothalamic, where the fibers of this nerve cross the midline of the brain, forming the chiasma opticum. These fibers contact each other only in the base of the chiasma opticum. The efferent projections of the nervus opticus exit the braincase through a foramen located between the frontal, orbitosphenoid and pterosphenoid (Fig. 2). 
Truncus cerebri. The truncus cerebri is ventrally located in the brain, and is comprised by the rhombencephalon and mesencephalon. It is more precisely located in the region between the posterior portion of the mesencephalon and the anterior portion of medulla spinalis. Most cranial nerves exit the efferent projections from the truncus cerebri, except for the nervus olfactorius and nervus opticus. The cranial nerves leaving the truncus cerebri include: nervus oculomotorius, nervus trochlearis, nervus trigeminus, nervus abducens, nervus facialis, nervus octavus, nervus glossopharyngeus, nervus vagus, nervus linea lateralis anterior, and nervus linea lateralis posterior. Proportional length variations of the truncus cerebri among species examined were not found (Figs. 5, 10).

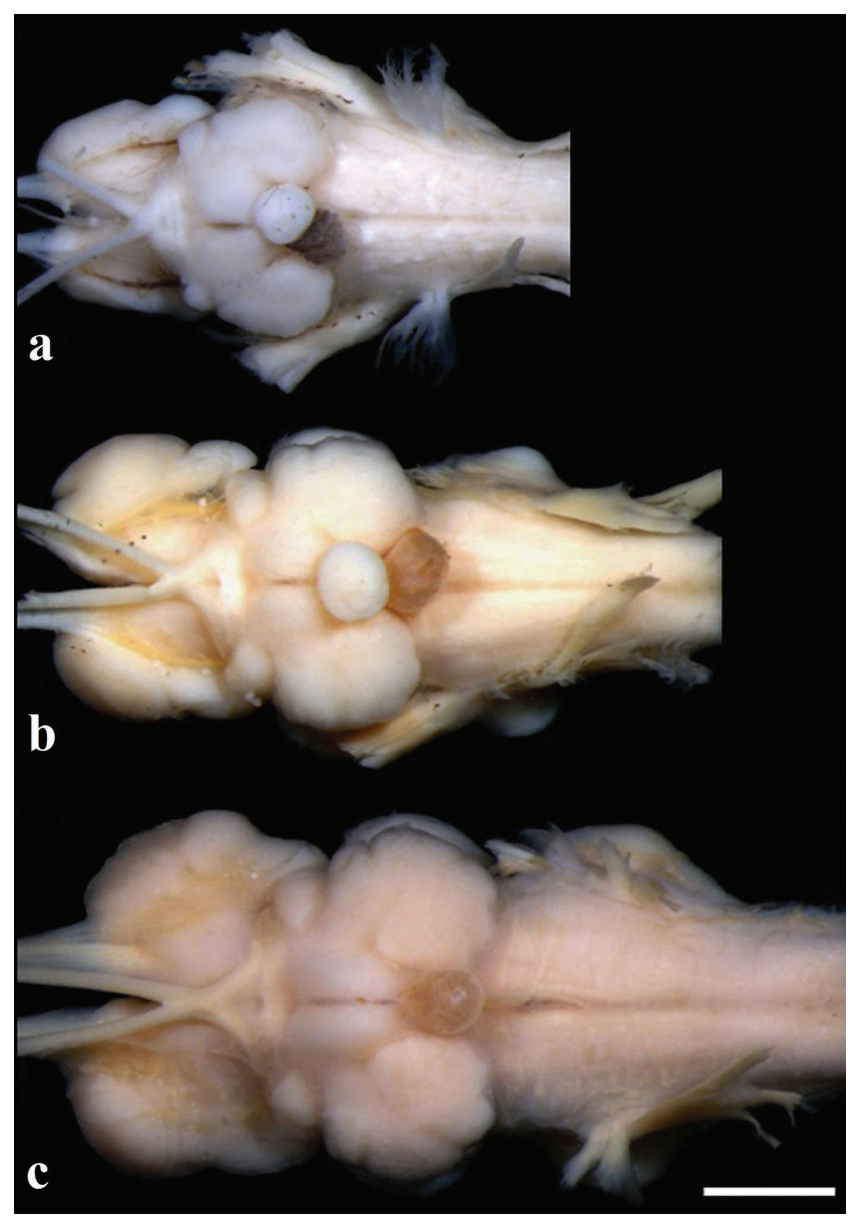

Fig. 10. Brain in ventral view: (a) Pseudopimelodus bufonius, MZUEL 5744, $118.2 \mathrm{~mm} \mathrm{SL}$, (b) P. charus, MZUEL 6488, $123.7 \mathrm{~mm} \mathrm{SL}$, (c) P. mangurus, MZUEL 2795, $175.7 \mathrm{~mm}$ SL. Scale bar $=2 \mathrm{~mm}$. (The hypophysis of $P$. mangurus is not shown because it was damaged during dissections).

Diencephalon. The lobus inferior hypothalami is located at the ventral portion of the diencephalon, in a region posterior to the chiasma opticum, ventral to the truncus cerebri and the tectum opticum, posterior to the telencephalon, and lateral to the hypothalamus. The lobus inferior hypothalami is semi-circular, with the anterior portion slightly smaller than the posterior portion. The hypophysis is circular, and anchored medially on the hypothalamus. The hypothalamus is located at the ventral portion of the diencephalon, posterior and above the lobus inferior hypothalami. The hypothalamus is also semicircular, with the medial portions straight (Figs. 5, 7, 10).

In all examined species of Pseudopimelodus, the length of the lobus inferior hypothalami is longer than that of the tectum opticum, but significantly longer $(\mathrm{p}=0.006)$ in $P$. bufonius in relation to the BL (Table 1, Fig. 4).

Telencephalon. In all examined species of Pseudopimelodus, the telencephalon is anterior to the tectum opticum and posterior to the bulbus olfactorius in lateral view. Less than half the length of the posterior portion of the telencephalon is positioned ventrally to the corpus cerebelli in dorsal and lateral views. The telencephalon is longitudinally elongated and somewhat cylindrical, with both the anterior and posterior margins rounded. The anterior margin of the telencephalon is slightly smaller than the posterior one in P. bufonius (Figs. 5, 8, 9, 10). The length of the telencephalon is longer than the lobus inferior hypothalami and the tectum opticum. The length of the telencephalon in relation to $\mathrm{BL}$ is significantly ( $\mathrm{p}=0.04$ ) longer in P. bufonius (Table 1, Fig. 4).

The bulbus olfactorius is stalked and is positioned at the anterior portion of the brain. The structure is ventral to the nasal bone, located near the articulation between the lateral ethmoid and the vomer (Fig. 2). The bulbus olfactorius is rounded. It is connected to the olfactory epithelium via the nervus olfactorius, and to the telencephalon via the nervus tractus olfactorius. The olfactory epithelium is rounded, with the anterior edge slight smaller than the posterior one. It is laterally curved with a large amount of lamellae on each side, with the appearance of a feather (Fig. 5).

\section{Discussion}

Gross morphological and morphometric differences were detected among the brains of Pseudopimelodus bufonius, P. charus and P. mangurus. No intraspecific variation was observed, though this may be related to the specimens examined. These findings highlight the validity and importance of characters derived from the anatomy of the brain as diagnostic even among closely related species. As would be expected, some features are shared by all examined species of Pseudopimelodus: the longer relative length of the corpus cerebelli and the tectum opticum, the small relative length of the lobus facialis and the lobus vagi, and the small relative width of the eminentia granularis. Given that shared patterns of morphological encephalic structures might be interpreted in an ecological context (Kotrschal et al., 1998), some considerations on the possible adaptive significance of those features in Pseudopimelodus are presented below. 
The corpus cerebelli is relatively large in all examined species of Pseudopimelodus. This condition might be related to a higher degree of motor coordination during swimming. Species of Pseudopimelodus live among trunks, rocks and roots on the bottom and river banks (Shibatta, 1998). Even though they live in a structurally complex environment, these fishes are obviously able to quickly capture prey and hide from predators. A similar enlargement of the corpus cerebelli was reported by Bauchot et al. (1989) in Rhyacichthys aspro (Valenciennes, 1837) (Perciformes: Rhyacichthyidae), which also lives in rapids of mountain rivers with rocky bottoms. In both cases, it is presumed that great accuracy in terms of movement is required, and the relatively large corpus cerebelli may be related to this. Despite the lack of information on the role of the corpus cerebelli in fish, it is generally accepted that this part of the brain is essential in sensorimotor integration (Meek \& Nieuwenhuys, 1998; Nieuwenhuys et al., 1998; Butler \& Hodos, 2005). Sharks and teleosts with strong-swimming and wide range of hunting maneuvers have increasing in the relative size, volume and foliation of the corpus cerebelli (Lisney \& Collin, 2006).

In all species of Pseudopimelodus examined the tectum opticum is also large, whereas the eminentia granularis, lobus facialis, and lobus vagi are relatively small. Together, those conditions may indicate a rather elaborate feeding behavior. The corpus cerebelli receives sensory input from various regions of the central nervous system, including the lateral line, auditory, visual, vestibular, somatosensory, and mainly sensorimotor systems, which provide spatial orientation, proprioception, and coordination of eye movements. In the corpus cerebelli the sensory input from those regions of the central nervous system are processed in order to provide balance and motor coordination of the body (Kotrschal et al., 1998; Butler \& Hodos, 2005). The tectum opticum, in turn, receives sensory information from the retina through the optic nerve, and is also responsible for generating signals that provides coordination of the motor response (Meek \& Nieuwenhuys, 1998). Moreover, it also receives information from the auditory, and somatosensory systems, enabling the structure to create retinotopic maps of the environment (Butler \& Hodos, 2005). The combination of the motor coordination of the body and also the coordination of the eyes promote responses from the corpus cerebelli and the tectum opticum that provide stimulus directing the fish to capture prey (Butler \& Hodos, 2005).

The lobus facialis and the lobus vagi are associated to gustative perception, receiving sensory information from taste buds in the barbels and mouth, and from taste buds present in the pharynx and gill arches, respectively (Meek \& Nieuwenhuys, 1998). The eminentia granularis is associated with mechanosensory perception that receives sensory input perceived by the lateral line mechanoreceptors (Finger, 1983; Meek \& Nieuwenhuys, 1998). Evans (1931, 1940) recognized functional groups of species of British cyprinoids based on morphological variations of the brain, in relation to their feeding habits. Those groups were based mainly on differences in feeding habits, reflected in the proportional lengths of the lobus facialis and the lobus vagi in relation to the corpus cerebelli and the eminentia granularis. In fishes that feed mainly on invertebrates, plant remnants and organic debris, the lobus facialis and the lobus vagi are larger, whereas the eminentia granularis and the tectum opticum are smaller. In fishes that feed primarily on other fishes, the opposite pattern was observed. Similar results were found on species of the Gadidae (Kotrschal et al., 1998). Studies on the feeding habits of pseudopimelodids (Shibatta 1998) indicate that $P$. mangurus is carnivorous. This observation is supported by the brain morphology, given that species of Pseudopimelodus have relatively large corpus cerebelli and tectum opticum, and small lobus facialis and lobus vagi.

Studies on brain architecture allows an increase in the number of informative characters for systematics, and also help in understanding the behavior and habits of fishes. In addition, it is noteworthy that there is a great horizon for studies on brain anatomy considering the huge diversity of teleosts.

Material Examined. Batrochoglanis melanurus: Brazil: MZUEL 3670, 1, 51.2 mm SL, Mato Grosso, Nobres, córrego Cancela, tributary of rio Cuiabá. Batrochoglanis raninus: Brazil: MZUEL 6035, 1, $76.7 \mathrm{~mm} \mathrm{SL}$, aquarium specimen. MZUSP 234072 of 24, 51.4-76.6 mm SL, Amazonas, Fonte Boa, igarapé Tucuxi, rio Solimões basin. Batrochoglanis villosus: Brazil: MZUEL 6037, 1, 143.2 mm SL, Maranhão, Turiaçu, rio Turiaçu. Cephalosilurus apurensis: Venezuela: MZUEL 6493, 1, 195.6 mm SL, Apure, Cano Bacaral. Cephalosilurus fowleri: Brazil: MZUEL 6040, 1, 275.0 mm SL, Minas Gerais, Três Marias, rio São Francisco. Lophiosilurus alexandri: Brazil: MZUEL 5377, 1, $58.7 \mathrm{~mm} \mathrm{SL}$, Minas Gerais, Três Marias, rio São Francisco. MZUSP 96276, 1 of 7, $73.1 \mathrm{~mm}$ SL, Três Marias, rio São Francisco. Microglanis cottoides: Brazil: MZUEL 6033, 3, 40.1-48.8 mm SL, Rio Grande do Sul, Canudos do Vale, rio Forquetinha. 29²2'4'S 5203'19'”W. Microglanis parahybae: Brazil: MZUEL 6393, 2, 39.1-42.0 mm SL, Rio de Janeiro, São Fidelis, rio Dois Rios, tributary of rio Paraíba do Sul. Microglanis aff. poecilus: Brazil: INPA 6828, 1, 20.9 mm SL, Pará, Trairão, rio Jamanxim. Pseudopimelodus bufonius: Brazil: MZUEL 5744, 6, 97.8-118.2 mm SL, Mato Grosso, Paranatinga, rio Culuene, tributary of rio Xingu. Pseudopimelodus charus: Brazil: MZUEL 6488, 1, 123.7 mm SL, Minas Gerais, São Roque de Minas, rio São Francisco. Pseudopimelodus mangurus: Brazil: MZUEL 2795, 2, 138.9-175.4 mm SL, Paraná, Diamante do Norte, rio Paranapanema. MZUSP 24449, 1, 88.5 mm SL, Mato Grosso do Sul, Ilha Solteira, rio Paraná.

\section{Acknowledgements}

The authors thank J. Birindelli and F. Jerep - Museu de Zoologia of the Universidade Estadual de Londrina (MZUEL), S. Ponzoni - Departamento de Fisiologia of the Universidade Estadual de Londrina, N. Menezes - Museu 
de Zoologia of the Universidade de São Paulo (MZUSP), and C. Dillman - Smithsonian Institution- for reading and commenting the manuscript, and M. de Pinna (MZUSP) for loan and permission to dissect specimens. We are also thankful to Universidade Estadual de Londrina and CNPq for financial support. OAS is a productivity researcher granted by Fundação Araucária (prot. 36.379, 414/2013).

\section{References}

Abrahão, V. P. \& F. M. R. S. Pupo. 2014. Técnica de dissecção do neurocrânio de Siluriformes para estudo do encéfalo. Boletim Sociedade Brasileira de Ictiologia, 112: 21-26.

Atema, J. 1971. Structures and functions of the sense of taste in the catfish (Ictalurus natalis). Brain Behavior and Evolution, 4: 273-294.

Bauchot, R., J. E. Randall, J. M. Ridet \& M. L. Bauchot. 1989. Encephalization in tropical teleost fishes and comparison with their mode of life. Journal fur Hirnforschung, 30: 645-669.

Birindelli, J. L. O. \& O. A. Shibatta. 2011. Morphology of the gas bladder in bumblebee catfishes (Siluriformes, Pseudopimelodidae). Journal of Morphology, 272: 890-896.

Butler, A. B. \& W. Hodos. 2005. Comparative vertebrate neuroanatomy: evolution and adaptation. 2nd ed. Hoboken, N. J., Wiley-Interscience. $715 \mathrm{p}$.

Carl Zeiss. 2009. Takeoff guide AxioVision. Tutorial to get started with the AxiVision Imaging System (Based on released 4.7.2 december 2008). Jena, De, Carl Zeiss Microimaging GmBH. 35p. Available from: www.usask.ca/biology/scopes/ axivision \% 204-7-2\%20Takeoff\%guide.pdf.

Datovo, A. \& R. P. Vari. 2014. The adductor mandibulae muscle complex in lower teleostean fishes (Osteichthyes: Actinopterygii): comparative anatomy, synonymy, and phylogenetic implications. Zoological Journal of the Linnean Society, 171: 554-622.

Eastman, J. T. \& M. J. Lannoo. 1995. Diversification of brain morphology in Antarctic Notothenioid fishes: basic descriptions and ecological considerations. Journal of Morphology, 223: 47-83.

Eastman, J. T. \& M. J. Lannoo. 2001. Anatomy and histology of the brain and sense organs of the Antarctic eel cod Muraenolepis microps (Gadiformes; Muraenolepididae). Journal of Morphology, 250: 34-50.

Eastman, J. T. \& M. J. Lannoo. 2003a. Diversification of brain and sense organ morphology in Antarctic dragonfishes (Perciformes: Notothenioidei: Bathydraconidae). Journal of Morphology, 258: 130-150.

Eastman, J. T. \& M. J. Lannoo. 2003b. Anatomy and histology of the brain and sense organs of the antarctic plunderfish Dolloidraco longedorsalis (Perciformes: Notothenioidei: Artedidraconidae), with comments on the brain morphology of other artedidraconids and closely related harpagiferids. Journal of Morphology, 255: 358-377.

Eastman, J. T. \& M. J. Lannoo. 2004. Brain and sense organ anatomy and histology in hemoglobinless Antarctic icefishes (Perciformes: Notothenioidei: Channichthyidae). Journal of Morphology, 260: 117-140.

Eastman, J. T. \& M. J. Lannoo. 2007. Brain and sense organ anatomy and histology of two species of phyletically basal non-Antarctic thornfishes of the Antarctic suborder Notothenioidei (Perciformes: Bovichtidae). Journal of Morphology, 268: 485-503.
Eastman, J. T. \& M. J. Lannoo. 2008. Brain and sense organ anatomy and histology of the Falkland Islands Mullet, Eleginops maclovinus (Eleginopidae), the sister group of the Antarctic Notothenioid fishes (Perciformes: Notothenioidei). Journal of Morphology, 269: 84-103.

Eastman, J. T. \& M. J. Lannoo. 2011. Divergence of brain and retinal anatomy and histology in pelagic Antarctic notothenioid fishes of the sister taxa Dissostichus and Pleuragramma. Journal of Morphology, 272: 419-441.

Evans, H. M. 1931. A comparative study of the brains in British Cyprinoids in relation to their habits of feeding, with special reference to the anatomy of the medulla oblongata. Proceedings of the Royal Society B: Biological Sciences, 108: 233-257.

Evans, H. M. 1940. Brain and body of fish: a study of brain pattern in relation to hunting and feeding in fish. London, Technical Press $164 \mathrm{p}$.

Finger, T. E. 1983. Organization of the teleost cerebellum. Pp. 261-284. In: Northcutt, R. G. \& R. E. Davis (Eds.). Fish neurobiology. Ann Arbor, University of Michigan Press.

Gonda, A., G. Herczeg \& J. Merilä. 2011. Population variation in brain size of nine-spined sticklebacks (Pungitius pungitius) local adaptation or environmentally induced variation? BMC Evolutionary Biology, 11: 75 (1-11p.).

Ihaka, R. \& R. Gentleman. 1996. R: A language for data analysis and graphics. Journal of Computational and Graphical Statistics, 5: 299-314.

Ito, H., Y. Ishikawa, M. Yoshimoto \& N. Yamamoto. 2007. Diversity of brain morphology in teleosts: brain and ecological niche. Brain, Behavior and Evolution, 69: 76-86.

Kotrschal, K., M. J. van Staaden \& R. Huber. 1998. Fish brains: evolution and environmental relationships. Reviews in Fish Biology and Fisheries, 8: 373-408.

Kotrschal, A., L. F. Sundström, D. Brelin, R. H. Devlin \& N. Kolm. 2012. Inside the heads of David and Goliath: environmental effects on brain morphology among wild and growthenhanced coho salmon Oncorhynchus kisutch. Journal of Fish Biology, 81: 987-1002.

Lannoo, M. J. \& J. T. Eastman. 2000. Nervous and sensory system correlates of an epibenthic evolutionary radiation in Antarctic Notothenioid fishes, genus Trematomus (Perciformes; Nototheniidae). Journal of Morphology, 245: 67-79.

Lecchini, D., G. Lecellier, R. G. Lanyon, S. Holles, B. Poucet \& E. Duran. 2014. Variation in brain organization of coral reef fish larvae according to life history traits. Brain, Behavior and Evolution, 83: 17-30.

Lisney, T. J. \& S. P. Collin. 2006. Brain morphology in large pelagic fishes: a comparison between sharks and teleosts. Journal of Fish Biology, 68: 532-554.

Lundberg, J. G. 1982. The comparative anatomy of the toothless blindcat, Trogloglanis pattersoni Eigenmann, with a phylogenetic analysis of the ictalurid catfishes. Miscelaneous Publications, Useum of Zoology, University of Michigan, 163: $1-85$.

Lundberg, J. G., A. H. Bornbusch \& F. Mago-Leccia. 1991. Gladioglanis conquistador n. sp. from Ecuador with diagnoses of the subfamilies Rhamdiinae Bleeker and Pseudopimelodidae N. Subf. (Siluriformes: Pimelodidae). Copeia, 1991: 190-209.

Meek, J. \& R. Nieuwenhuys. 1998. Holosteans and teleosts. Pp. 759-937. In: Nieuwenhuys, R., H. J. Ten Donkelaar \& C. Nicholson. (Eds.). The Central Nervous System of Vertebrates. Berlin: Springer-Verlag. 
Nieuwenhuys, R., H. J. ten Donkelaar \& C. Nicholson. 1998. The Central Nervous System of Vertebrates. Berlin, Springer. 3v. (2219p).

Northcutt, R. G. 2004. Taste buds: development and evolution. Brain, Behavior and Evolution, 64: 198-206.

Northcutt, R. G. 2008. Forebrain evolution in bony fishes. Brain Research Bulletin, 75: 191-205.

Pupo, F. M. R. S. 2011. Anatomia comparada da morfologia externa do sistema nervoso central da família Callichthyidae (Teleostei: Ostariophysi: Siluriformes) e suas implicações filogenéticas. Unpublished MSc. Dissertation, Universidade Federal do Rio de Janeiro, Rio de Janeiro. 97 p.

Rosa, A. C., F. O. Martins \& F. Langeani. 2014. Miniaturization in Otothyris Myers, 1927 (Loricariidae: Hypoptopomatinae). Neotropical Ichthyology, 12: 53-60.

Ruiz, W. B. G. \& O. A. Shibatta. 2011. Two new species of Microglanis (Siluriformes: Pseudopimelodidae) from the upper-middle rio Araguaia basin, Central Brazil. Neotropical Ichthyology, 9: 697-707.

Shibatta, O. A. 1998. Sistemática e evolução da família Pseudopimelodidae (Ostariophysi, Siluriformes), com a revisão taxonômica do gênero Pseudopimelodus. Unpublished Ph.D. Dissertation, Universidade Federal de São Carlos, São Carlos, 357p.

Shibatta, O. A. 2003a. Phylogeny and classification of "Pimelodidae". Pp. 385-400. In: Arratia, G., B. G. Kapoor, M. Chardon \& R. Diogo. Catfishes. Enfield, Science Publishers.
Shibatta, O. A. 2003b. Family Pseudopimelodidae (Bumblebee catfishes, dwarf marbled catfishes). Pp. 401-405. In: Reis, R. E., S. O. Kullander \& C. J. Ferraris Jr. (Orgs.). Check list of the freshwater fishes of South and Central America. Porto Alegre, Edipucrs.

Shibatta, O. A. 2013. Pseudopimelodidae. Pp. 338-346. In: Queiroz, L. J., G. Torrente-Vilara, W. M. Ohara, T. H. S. Pires, J. Zuanon \& C. R. C. Doria (Orgs.). Peixes do rio Madeira. São Paulo, Dialeto Latin American Documentary.

Tong, S. -L. \& T. E. Finger. 1983. Central organization of the electrosensory lateral line system in bullhead catfish Ictalurus nebulosus. Journal of Comparative Neurology, 217: 1-16.

Wiley, E. O. \& G. D. Johnson. 2010. A teleost classification based on monophyletic groups. Pp. 123-182. In: Nelson, J. S., H.-P. Schultze M. V. H. Wilson \& G. Arratia Fuentes. (Eds.). Origin and phylogenetic interrelationships of teleosts: honoring Gloria Arratia: proceedings of the International Symposyum at the ASIH Annual Meeting in St. Louis, Missouri, 2007. München, Verlag Dr. Friedrich Pfeil.

Submitted December 03, 2013 Accepted March 10, 2015 by Luiz Malabarba Published June 30, 2015

\section{ERRATA}

Page 256, caption of Fig. 1:

Where read: MZUSP 94855 ... Paranatinga, rio Culuene, tributary of the rio Xingu. Photo by José L. O. Birindelli. Should read: MZUSP 97220 ... rio Curuá, Iriri-Xingu drainage, near town of Castelo dos Sonhos. Photo by Mark Sabaj-Pérez.

Page 263, Acknowledgements:

Include in the last line: To Mark Sabaj-Pérez for the photograph of Pseudopimelodus bufonius.

All changes are already incorporated in the online HTML version of this article available at http://www.scielo.br/ni 